\title{
Agricultural Marketing Issues and Strategies in Western China
}

\author{
Jiyan XU \\ College of Mathematics and Information, \\ China West Normal University, \\ Nanchong Sichuan, China. \\ Siny99_cq@sohu.com
}

\begin{abstract}
Agricultural products in Western China are rich and various, the quality is very good, but not all agricultural products sell very well in market, some products have encountered marketing problems. Such as slow-moving, volatile price movements, lack of awareness on brand marketing and so on. To solve these problems, we should make agricultural mode transition to modern intensive and large-scale agriculture, reduce circulation and use brand marketing strategy, so as to promote the sales of agricultural products in western.
\end{abstract}

Keywords-Western China; agricultural products; unmarketable; price volatility; brand marketing; strategies

\section{I.INTRODUCTION}

The agricultural marketing refers to activities of potential exchange of agricultural products; the purpose is meeting people's needs and desires. The main body of marketing on agricultural products is individuals and groups of agricultural production and management. There are agricultural marketing activities in the whole process of agricultural production, circulation and trading. Western region in China has rich agricultural resources, for the variety and high quality of western agricultural products, some agricultural products are booming sales, but some are difficult to sell, such as jujube in Xinjiang, potato in Inner Mongolia, and onion in Gansu. They all have excellent quality, but in recent years there have been poor sales and price fluctuations. We will investigate these cases to identify the problems of western agricultural marketing, and work over marketing strategy for Western agricultural products.

\section{II.MARKETING SitUATION ON WESTERN AGRICULTURAL PRODUCTS}

Xinjiang province has land resources and plenty of light and heat, Xinjiang has a unique advantage of development on agriculture and animal husbandry. Xinjiang is rich in sheep, cotton, grapes, figs, thin-skinned walnuts, jujube, cantaloupe and other agricultural products. Sheep, cotton and grapes sell very well, but jujube has appeared unsalable condition. There has been slow-moving of jujube in Alar city in fall of 2011. The planting area of Jujube in Alar city reached 654,000 acres in this year, and production reached 24 million tons, but not many buyers went to see the goods and the price was also low. Jujube sold for 40 Yuan per kilogram in 2010, but in 2011 it dropped a dozen Yuan per kilogram, so farmers were miserable.

Inner Mongolia concludes broad area; it is the largest provincial-level administrative unit in span from east to west. It is also rich in resources and abundant with cashmere, wheat, corn, potato, soybeans, cattle and sheep meat, sheep and cattle dairy products and other agricultural products. Cashmere, wheat, and corn are booming sales, but Potato is on the contrary. In 2011, potato of Inner Mongolia also encountered unmarketable situation, the potato production has increased significantly, the planting area was over 11.4 million acres, and the entire acreage of potato production exceeded 10 million tons. However, the harvest potatoes encountered difficult sales. The purchase price was very low, it was 2 Yuan per kilogram in 2010, and dropped to 0.8 Yuan per kilogram in 2011. Farmers lost a lot.

Gansu is a province with abundant sunshine, large difference on temperature between day and night, fewer pests and diseases. The province is rich in herbs, wheat, watermelon, apple, black seeds, lily, onion and other agricultural products. Herbal materials, watermelon and wheat are booming sales while onions and apples suffered unsalable condition. In October 2011, onion encountered the same slow-moving situation in Suzhou district of Jiuquan city of Gansu Province. The planting area of Onions reached 58,000 acres, and the total output was 406,000 tons. There is an increase of 136,000 tons on production in comparison with 2010, but price fell from 800 Yuan per ton in 2010 to 180 Yuan per ton in 2011. For the low price, the farmers suffered heavy losses. Apple of Tianshui city in Gansu Province suffered a decline in sales in November 2012. The apple production reached 880,000 tons, in which the total production of Huaniu Apple nearly reached 600,000 tons. Unluckily, hundreds of thousands of tons of high-quality apples still hanged in branches until the end of year

\section{MARKETING ISSUES ON WESTERN AGRICULTURAL PRODUCTS}

\section{A. Unmarketable Agricultural Products}

The production of western agricultural products is very big and they have high quality, but it has repeatedly declined in sales. The reasons are as follows:

1) Blind Planting

Farmers can not calmly analyze the needs of market, but to take the herd way. When money effect appears on some products, farmers grow this agriculture in herd 
phenomenon. As a result of this, agricultural production is of overcapacity and faces oversupply situation. One of reasons about unsalableness of Xinjiang jujube and Inner Mongolia potatoes is blind planting. In 2010, both agricultural products had money effect and sold well, and the price was high. Farmers saw the sweetness to follow the trend; many farmers expanded the cultivation area. However in 2011, production increased substantially and caused over-production, but the rise of needs in the market did not follow, so there has been slow-moving situation.

2) The Problem of Circulation of Agricultural Products

The location of western agricultural products is remote. In order to make western agricultural products to the population density in eastern China, it requires good circulation. However, rising fuel prices, many dense highway toll , and demand of rising wage by the transport drivers, all lead to a crazy increase in transportation cost and circulation cost. Means of transport is relatively backward, in addition, there are unreasonable logistics planning and excessive circulation in western circulation of agricultural products process, so they lead to big circulation costs and it's difficult to sell.

\section{B. Volatility and Instability of Price about Agricultural Products}

First, when money effect appears in some agricultural products, farmers herd to grow this agricultural product. As a result, this causes excess production and oversupply situation. Farmers reduce or stop cultivation of agricultural products when a product has a loss, and this leads that agricultural product is in short supply and then the price spikes. So the price rises and falls into a cycle, and it's unstable.

Second, also for reasons of idle speculation, the speculators buy a large number of such agricultural products when they encounter good price and hoard them not to sell. The result will cause prices rising in short time. When the hoarding agricultural products are sold by the speculators, the price will fall, so the price is very unstable.

\section{Lack of Awareness on Brand Marketing}

In western rural areas in China, there are few farmers know brand marketing. Due to various reasons, they do not build brands of agricultural products in terms of technology, quality, variety, trademarks, packaging, advertising and other all-rounds. The lack awareness on brand creation causes that the ability is not strong to compete in international market and Chinese market. They just rely on the sale of raw materials-agricultural products,the result can only be price competition, so it is difficult to make money for farmers. Also, the government is lack of effective guidance in this regard.

\section{D.Immaturely Developing of Agricultural Cooperatives}

Agricultural cooperatives are on the basis of contract management by rural household, they are mutual aid economic organizations which are united voluntarily, and they have democratic management by operators of similar agricultural production or providers and users of similar agricultural production and service. In the past few years, there has been establishment of agricultural cooperatives in western rural areas, but there are no many mature agricultural cooperatives. There are many issues on shortage of funds, lack of talent, lack of trust and members breach in most of them.

\section{WESTERN AgRicUltural MARKETING STRATEgIES}

\section{A. Changing Agricultural Model}

Unmarketable condition of western agricultural products looks forward to changing pattern of agriculture. According to the laws of market to configure the relevant elements of agricultural production, agriculture is promoted to shift from traditional single mode to a large-scale modern mode. And it should realize integration of production and market, control the layout and structure of agricultural production by market needs, and achieve the full-range information communication, so that it can avoid the problem of blind planting and asymmetric information, as well as the problem of fluctuations in the prices of agricultural products.

Of course, promoting transformation of agricultural model inevitably needs to create a new mode of environment in the policy level. On the one hand, we should further improve the land transfer mechanism, strengthen social security for farmers and give farmers more autonomy for involving in the scale of operation. On the other hand, it is necessary to further strengthen the support for the development of agricultural industrialization; it is necessary to encourage more capital into the agricultural industry and develop more agricultural enterprises which collect production, processing and sales.

\section{B. Reducing the Circulation and Improving the Circulation Environment}

The location of western agricultural products is remote. In order to send western agricultural products for different places nationwide, it requires good circulation. Relevant government should take advantage of macro-control to reduce circulation, the cost of tolls, the price of oil and other middle relief related taxes, and open up direct selling market of agricultural products and encourage farmers to homegrown.

Government also needs to strengthen the construction of rural modern circulation system, introduce into large-scale urban commercial circulation enterprises to actively participate. They must make full use of advantages of these enterprises with management modes, enterprise management philosophy and management tools, combine with the local advantages of county, township and rural business enterprises, and promote jointly the rural market system building. First, it should secure the existing agricultural store business, actively expand the scope of business of farm shops, and enhance capabilities 
of rural circulation network service. Second, it needs to focus on strengthening rural commodity distribution system and planning, and it needs to improve the efficiency of the rural circulation network logistics. Third, it should cultivate rural circulation system of the main building. Fourth, government departments intensively give policy support to further improve the rural circulation network system and meet the requirements of agricultural producers and consumers.

\section{C.Using Brand Marketing Strategies for Agricultural products}

First, it's necessary to establish a good market positioning of the brand. The western agricultural brand should be based on its own characteristics, and develop agricultural products brand through local conditions. Furthermore, there should be agricultural productions with characteristics on the basis of target market. Agricultural products, with strong advantage of western natural resource, will be able to build a brand on the product itself. Xinjiang, Inner Mongolia and Gansu Province are blessed with natural resources. Their productions can create special brands, healthy brands, green brands and high-quality ingredients brands. They can also use brand strategy about senior club positioning, geographical and cultural positioning.

Second, it's significant to publicize the brand, we should make a series of information on the brand accurately and effectively to consumers. Meanwhile, create integrated use of advertising, public relation, sale promotion and event marketing, we can make efforts to increase brand awareness and build a good image for the brand.

\section{D.Strengthening the Management of Agricultural Cooperatives and Enhancing the Effectiveness of Cooperatives}

Developing agricultural cooperatives is a powerful measure for improving agricultural cooperation, it is useful to enhance agricultural scale and resist risks. The western concerned departments should conscientiously do a good job about the implementation of preferential policies for agricultural cooperatives. What's more, if conditions permit, they should give priority for the water conservancy construction, investment in science and technology, credit, interest payment on loans, and agricultural insurance. Simultaneously, it's significant to strengthen talent cultivating of cooperatives, and promote development of modern agricultural cooperatives healthily.

In addition, various departments need to promote genuine cooperation of cooperatives, and contribute to the consistent interests between the initiator and members of cooperatives, also between enterprises and cooperatives. It will not only reduce the possibility of membership breach, but also enhance the economic efficiency of cooperatives, and ultimately enhance the cohesion of cooperatives.

\section{ACKNOWLEDGMENT}

Thanks for support of School Fund Research Projects in China West Normal University, the project number is 12A031.

\section{REFERENCES}

[1]Huang Qingfeng.The plight faced by the marketing of agricultural products and Countermeasures [J].TRADE INDUSTRY, November.2011, pp.40—43.

[2]Yuan Juan. Marketing strategy of agricultural products [J]. Modern Agricultural Science and Technology. 2008, pp.296-298.

[3]Kang Yong.Xinjiang agricultural products marketing channel innovation [J].Xinjiang Finance. February.2010, pp.75—77.

[4]Yin Shaoming.Xinjiang corporate marketing characteristics and innovation [J].Xinjiang Finance .April.2008, pp.90—94.

[5]Liu Qinghua.Analysis on adjustment and improvement of agricultural marketing channels in Inner Mongolia [J].China Management Informationzation. December.2011, pp.58—59.

[6]Chinese Agricultural Information Network. Ministry of Agriculture held a press conference farmer cooperatives model agency. [EB /OL ] .http: // www.gov.cn /xwfb /2011-10-27 /content_1979863. htm. [7]Tian Anguo.On the construction of farmer cooperatives [J].Agricultural Sciences. July.2012, pp.3128-3130. 